$\mathbb{T}$ periodica polytechnica

\author{
Civil Engineering \\ $55 / 2(2011) 199,204$ \\ doi: 10.3311/pp.ci.2011-2.12 \\ web: http://www.pp.bme.hu/ci \\ (c) Periodica Polytechnica 2011 \\ RESEARCH ARTICLE
}

\section{Permeability of well graded soils}

\author{
László Nagy
}

Received 2009-10-29, revised 2010-03-22, accepted 2011-06-01

\begin{abstract}
Coefficient of permeability $(k)$ values can be determined using a variety of on-site and laboratory methods. Indirect inference from the grading curve is a standard method used to determine the $k$ factor of fine granular soil types [12,13]. However, measurements and calculations may introduce inaccuracies in several ways - for instance, by ignoring the coefficient of irregularity.
\end{abstract}

\section{Keywords \\ Permeability of soils $\cdot$ laboratory test $\cdot$ empirical correlation . coefficient of uniformity $\cdot$ safety $\cdot$ well graded soil}

\section{Introduction}

The series of experiments underlying this study were designed to investigate how a flattened grading curve influences the coefficient of permeability $(k)$, provided $d_{10}$ is kept constant. The badly grading curve is normally characterised by Hazen's uniformity coefficient $\left(C_{U}\right)$. One can imagine two possible relationships between the coefficient of permeability and the flatness of the grading curve:

- the finer the grading of a soil type, the larger the coefficient of permeability, because fine grains can only partially fill the gaps between the large grains, and permeability will increase as gap size increases; or

- the finer the grading of a soil type, the smaller the coefficient of permeability, because fine grains will fill the gaps between the larger grains, and coarse grains will more or less "float" in a continuum of finer grains, leading to the formation of more compact soils of lower permeability.

Experiments can easily indicate which of these two a priori concepts is closest to the truth.

Several articles make reference to the uniformity coefficient as it relates to the coefficient of permeability [3, 5, 7, 20], frequently as part of a formula [1,2,17]. Unfortunately, the precise relationship between the two is not entirely evident.

Some technical books take it for granted that the $k$ of poorly graded soil types, which are typically associated with steep grading curves, will be an order of magnitude higher than that of finely graded soils, i.e. soils of a single grain will be less liquidtight than soils with an elongated grading curve, provided $d_{10}$ is constant [10].

The effect of three variables on the coefficient of permeability has been studied [18]. The value of $k$ can be determined as a function of $d_{10}$ based on differences in the uniformity coefficient. These figures can be used for compact through moderately compact (Figure 1) and non-cohesive soil types; from sand meal with silt to gravel. The curves suggest an inverse relationship between $C_{U}$ and $k$.

Beyer [2] processed data from multiple measurements, tabulating average values of $\mathrm{Cp}$. In his table, columns represent

\section{László Nagy}

Department of Geotechnics, BME, H-1111 Budapest, Múegyetem rkp. 3., Hungary

e-mail: EMAIL MISSING 


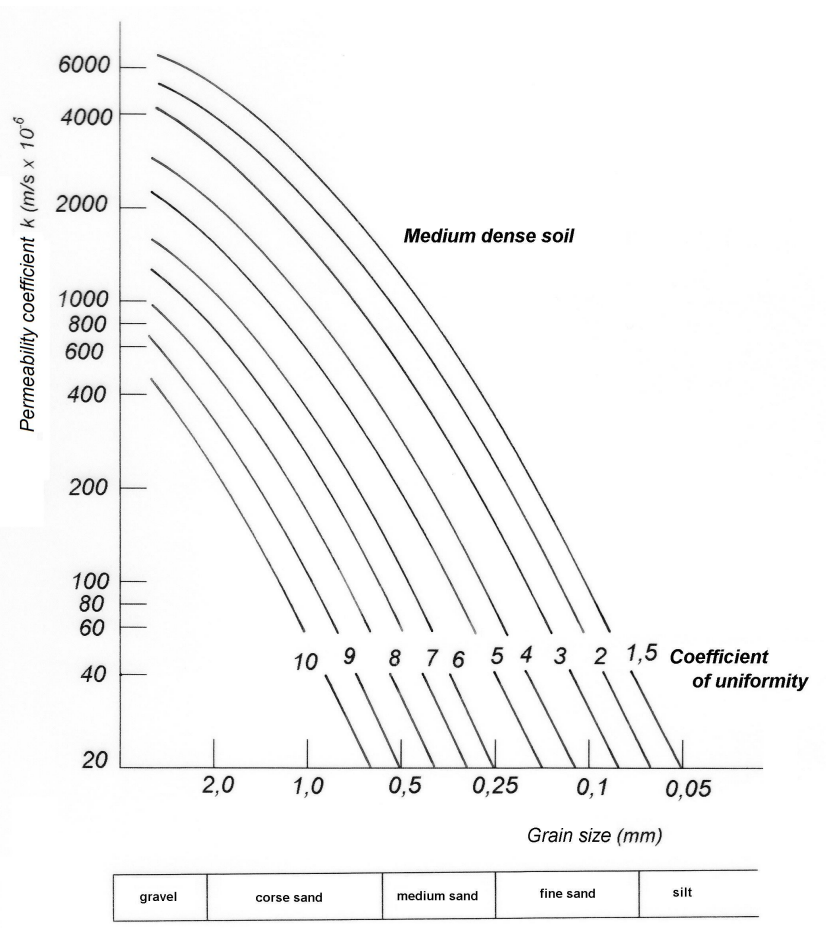

Fig. 1. The coefficient of permeability of moderately compact soils

values of $d_{10}$ while rows represent values of $d_{60}$. He arrives at the following equation for $\mathrm{k}$ :

$$
k=\left(\frac{A}{C_{U}+B}+C\right) d_{10}^{2}
$$

where $d_{10}$ is in $\mathrm{cm}$ and $\mathrm{k}$ in $\mathrm{m} / \mathrm{s}$. The constants $A, B$ and $C$ have to be selected from Table 1. A graphical representation of Bayer's data [8] again demonstrates an inverse relationship between $\mathrm{k}$ and $C_{U}$ in the $1<C_{U}<12$ range, though this relationship is less pronounced at higher $C_{U}$ values.

Tab. 1. The impact of soil compactness on the constant values in Bayer tables

\begin{tabular}{cccc}
\hline & Loose & Medium & Compact \\
\hline$A$ & 3,49 & 2,68 & 2,34 \\
\hline$B$ & 4,40 & 3,40 & 3,40 \\
\hline$C$ & 0,80 & 0,55 & 0,39 \\
\hline
\end{tabular}

Burmister [3] recommended using $d_{10}$. In the soil he studied, the uniformity coefficient and the coefficient of porosity equalled $C_{U}=1.5 e=0.75$ and $C_{U}=3.0 e=0.70$, respectively. There was an almost perfect match between the curves he predicted and his actual findings [20].

The Amer and Awad [1] formula for coarse sands refines the constant value of $C$ predicted by Kozeny [9]:

$$
k=C_{2} d_{10}^{2,32} C_{U}^{0,6} \frac{e^{3}}{1+e}
$$

This comparison suggests that the relationship between $C_{U}$ and $C p$ is nonlinear.
In contrast to earlier studies, Kozeny [9] improves the formula [17] by using a value for $d_{10}$ less than 1.0:

$$
k=1,2 C_{U}^{0,735} d_{10}^{0,89} \frac{e^{3}}{1+e}
$$

The use of this formula is recommended for medium and fine sands.

As seen in the formulas above, the uniformity coefficient shows up in both the numerator and the denominator and at different powers. One cannot help but admit that the exact relationship between the uniformity coefficient and the coefficient of permeability is less than clear.

\section{Methods}

To determine the coefficient of permeability of soils, a series of tests were constructed where measured results depended solely on the uniformity coefficient. To that end, the value of $d_{10}$ was fixed for each test in the series.

We studied the coefficient of permeability of finely graded soils in a laboratory using a large diameter device with variable water pressure. We measured the coefficient of permeability of various soils, varying the curves of flatness while keeping $d_{10}$ constant. The tests focused on fine granular and intermediate soil types. By varying the relative proportion of the coarser fraction in certain soil mixtures, we managed to reach values of $C_{U}>200$, an increase of almost two orders of magnitude. The internal diameter of the test equipment limited the grain size. The large diameter devices could not accommodate grains larger than half the diameter of the device. We ran three simultaneous tests of each grain distribution during the study and tried to keep the compactness of the samples identical for each test. After the permeability tests were completed, the grading curve of each of the three samples was determined, thus yielding values for $d_{10}$ and $C_{U}$.

The test series identified the coefficient of permeability and the grading curve simultaneously. The laboratory tests were performed on samples with saturated capillaries to avoid errors due to uneven saturation. Soil samples were subjected to a hydraulic gradient of $1<i<11$.

Model soils were composed of up to 12 fractions, if necessary, which eliminated the need for taking multiple individual local samples. Calculation of the predefined curve was cumbersome but the resulting tests were easier to carry out. As it is practically impossible to separate finer grains below $d=0.1$ by screening, we kept constant the proportion of sand meal and silt by adding a certain percentage of a soil type called "blue silt" to the mixture. Using this method we were able to determine the grain diameter $\left(d_{10}\right)$ associated with 10 mass percent, which was one of the most important properties for the purposes of the test. 


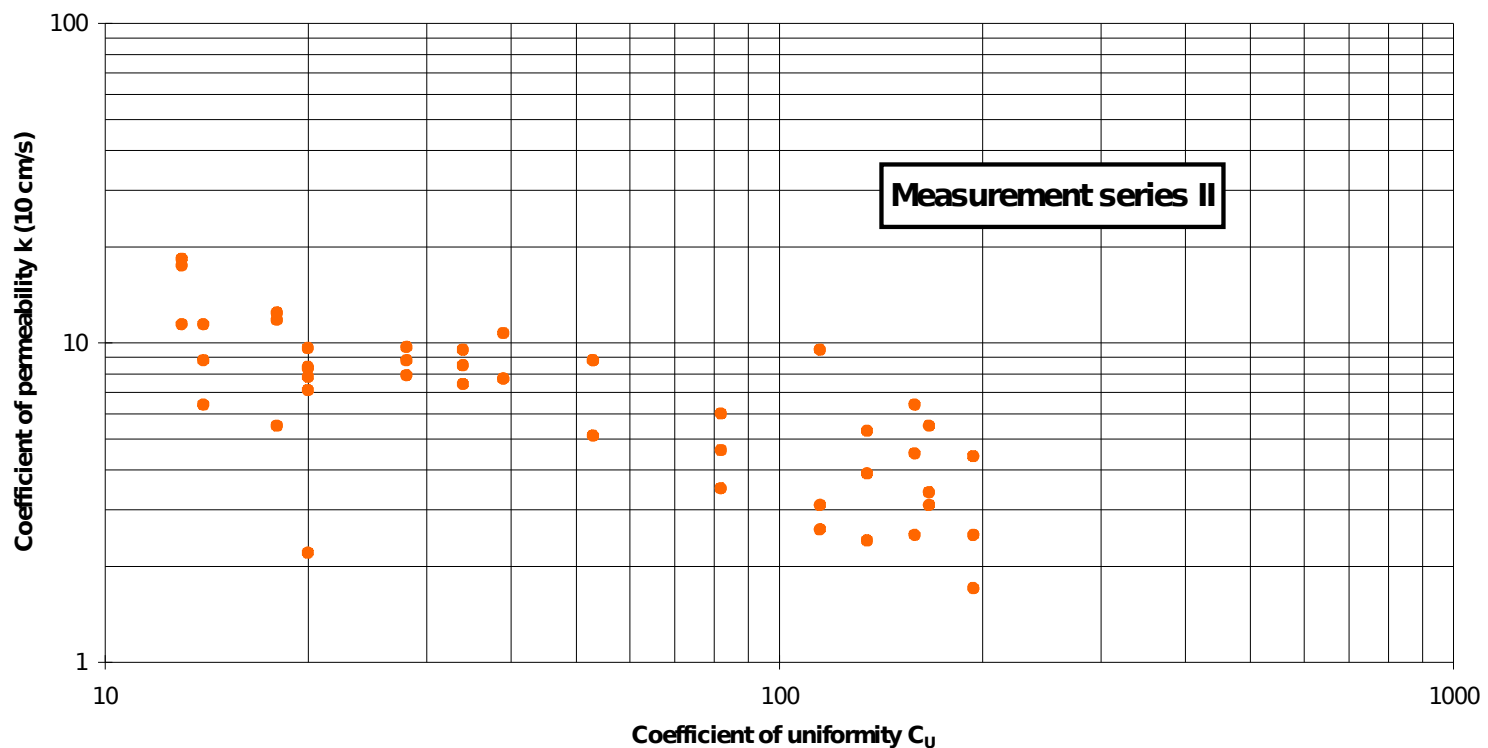

Fig. 2. Results of Measurement Series II

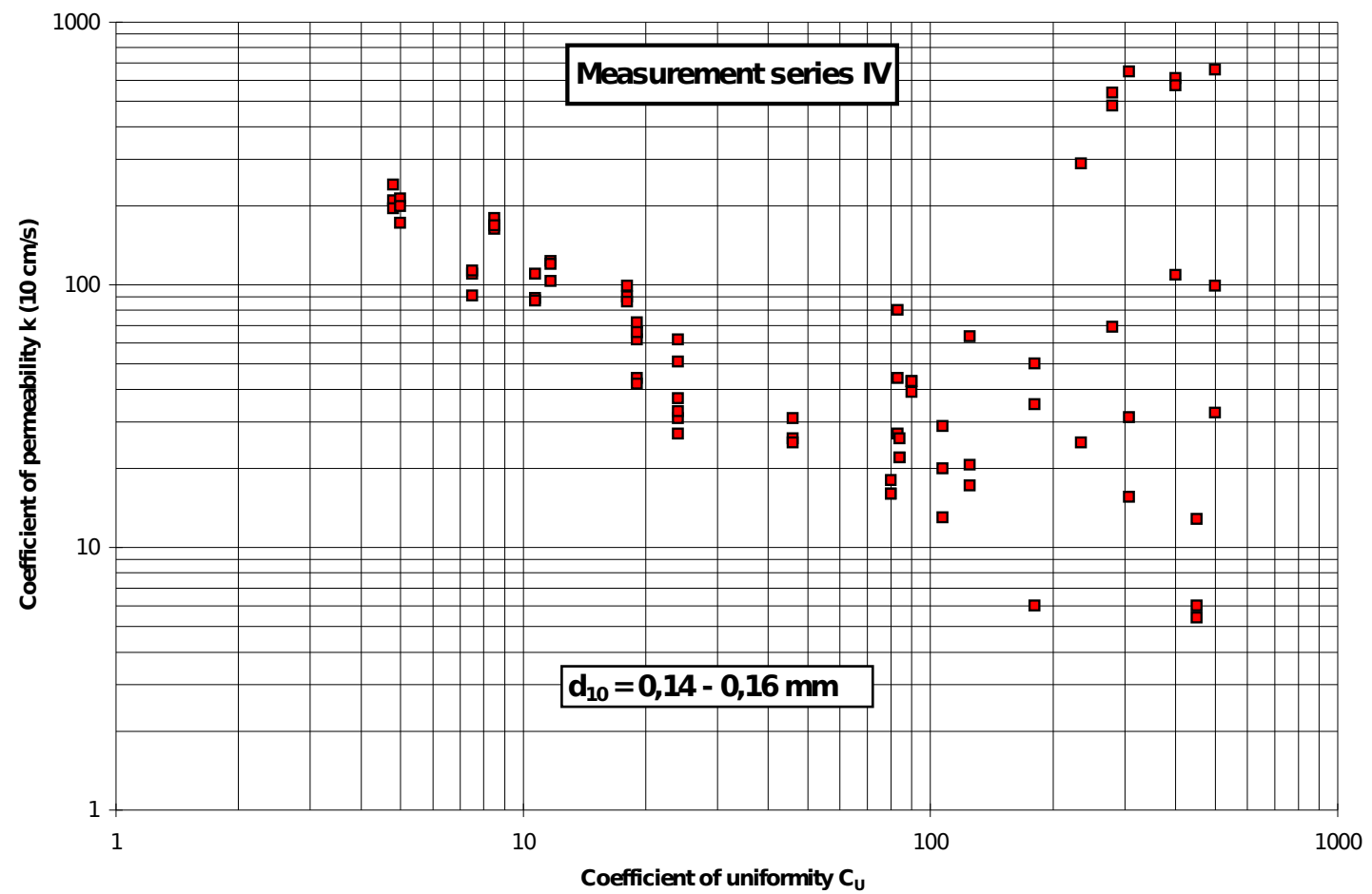

Fig. 3. Results Measurement Series IV 


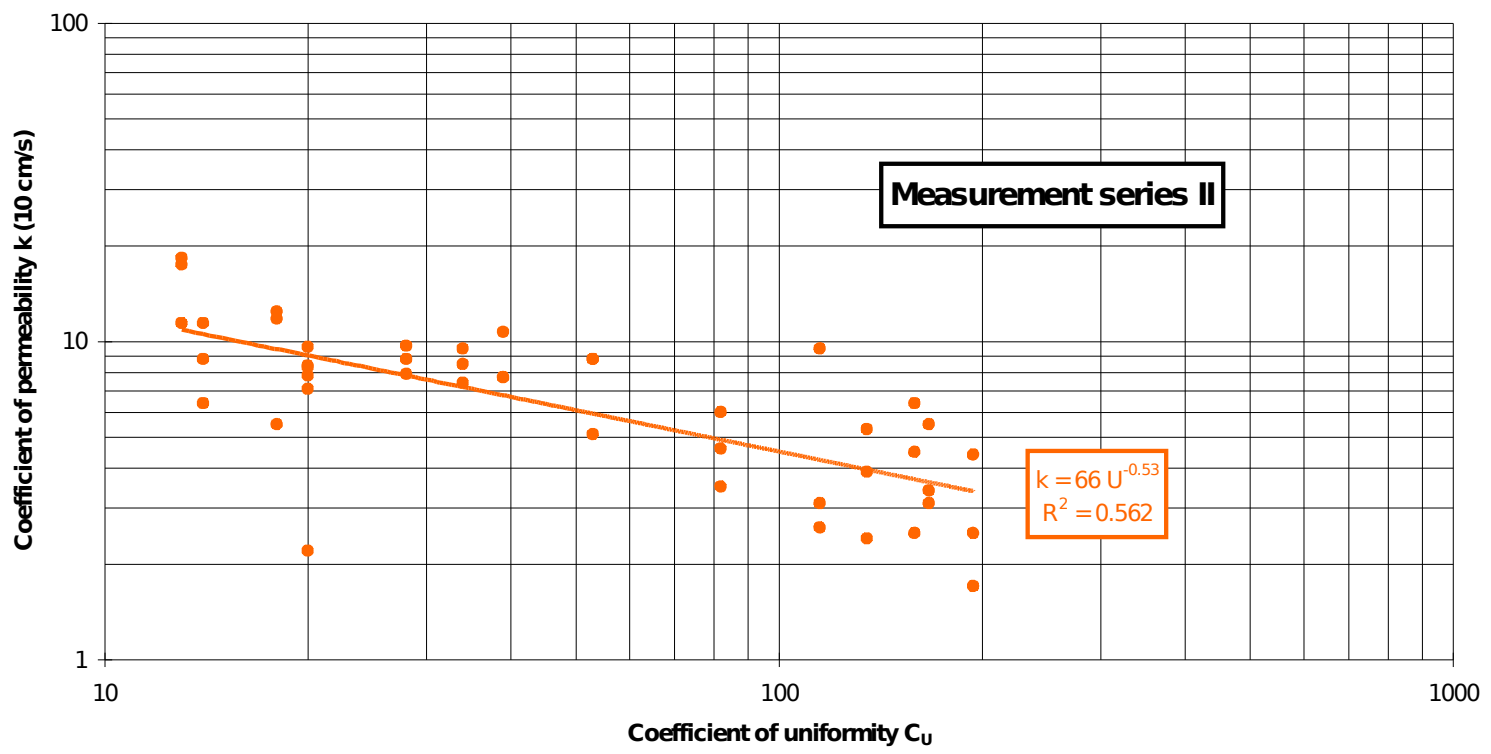

Fig. 4. Average Values and Boundary Curves at Series II

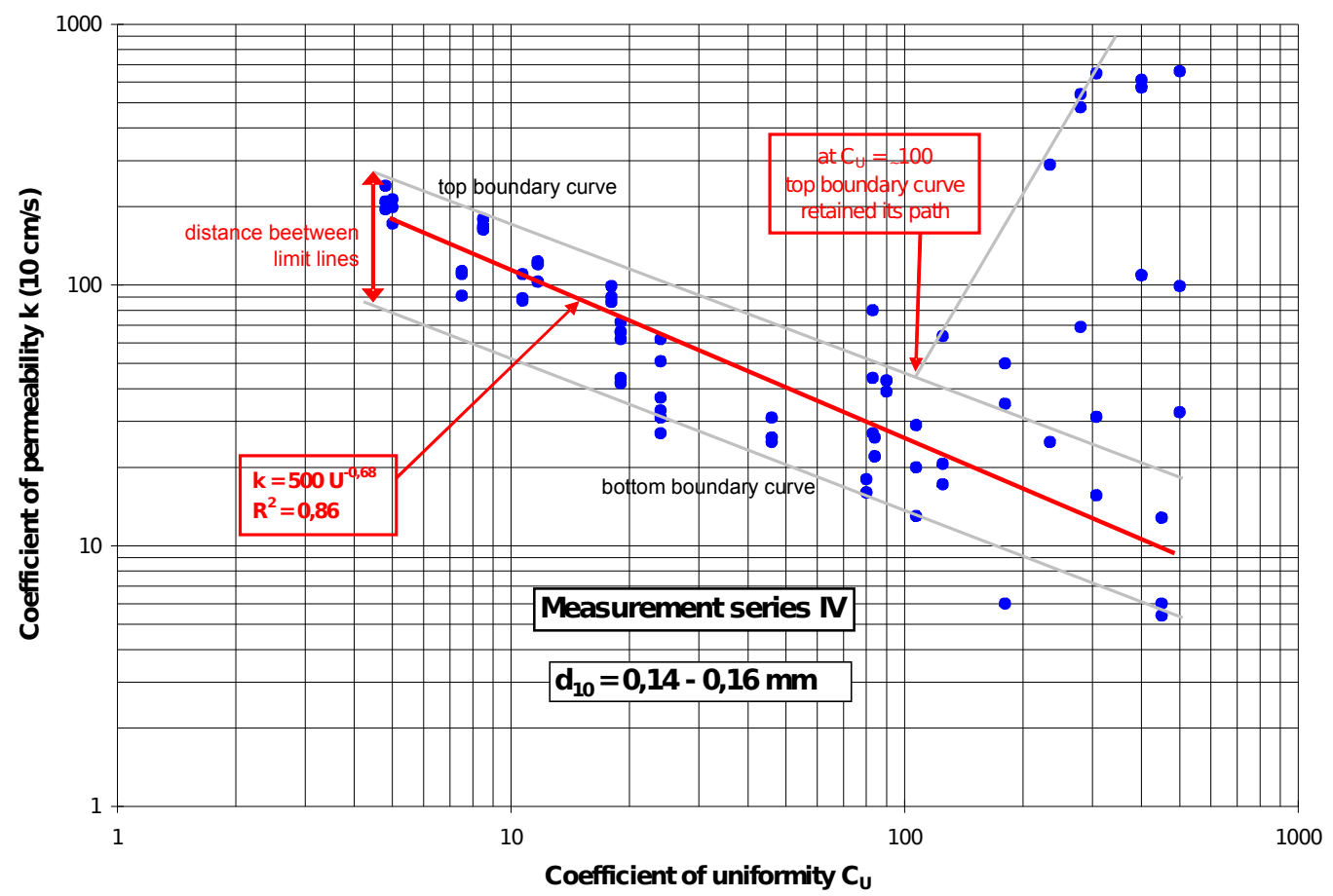

Fig. 5. Measurement series IV: Boundary Curves, Average Value and Trends 


\section{Measurement results}

The study involved the determination of the coefficient of permeability in a variable water pressure device 207 times and the plotting of 74 grading curves in 5 measurement series. The measurement series showed that grain diameters associated with 10 mass percent fell between the following ranges:

$\begin{array}{ll}\text { Measurement series I } & d_{10}=0.04-0.06 \mathrm{~mm} \\ \text { Measurement series II } & d_{10}=0.06-0.90 \mathrm{~mm} \\ \text { Measurement series III } & d_{10}=0.11-0.14 \mathrm{~mm} \\ \text { Measurement series IV } & d_{10}=0.14-0.16 \mathrm{~mm} \\ \text { Measurement series V } & d_{10}=0.28-0.32 \mathrm{~mm} .\end{array}$

Figures 2 and 3 show the findings of measurement series II and IV; the findings of each measurement series demonstrate that different $C_{U}$ values are associated with a different coefficient of permeability. The following conclusions can be made:

- The average of measured values and the boundary curves of the test findings can be approximated with a straight line on a double logarithmic scale;

- The straight lines belonging to the top and bottom boundary curves are almost parallel (see Figures 4 and 5 ;

- The difference between the straight lines associated with the top and the bottom boundary curve varied between 2 and 11 in the five measurement series (see Table 2);

- Consistently, the coefficient of permeability varied inversely with the uniformity coefficient, provided no washout occurred. For each order of magnitude increase in $C_{U}$, the coefficient of permeability decreased by 2.4 to 14.0 units.

- On average over the five series, the coefficient of permeability decreased by a factor of 6 for each order of magnitude decrease in the uniformity coefficient;

- For values of $C_{U}<100-160$, the bottom boundary of the coefficient of permeability retained its linearity on a double logarithmic scale, as shown in Figure 5 .

- For values of $C_{U}>100-160$ the top boundary curve showed a significant increase for certain samples, which might relate to the changes of soil structure in these samples (Figure 5). Table 2 presents the $C_{U}$ values found in each series where the top boundary curve demonstrated an increase;

- In measurement series IV, fine grains could not fill the voids between larger grains when the uniformity coefficient was over $C_{U}>100-120$, which yielded higher than expected values of the coefficient of permeability;

- If the washout of grains is prevented, the downward slope of the bottom boundary curve is visible even with uniformity coefficient values as high as $C_{U}=400-500$, (Figure 5);

- Measurement series IV and V indicated changes in the coefficient of permeability due to grain washout (see Figure 57, which occurred in two ways. On the one hand, we could measure coefficient of permeability values, which were larger by orders of magnitude (see the range $C_{U}>100$ ). On the other, $d_{10}$ rose from the original setting of $d_{10}=0.014-0.016$ to $d_{10}=0.020-0.035$ in the grading curve calculated after the test due to the absence of fine grains.

- If the coefficient of permeability is calculated from the value of $d_{10}$ and the reading curve, the relationship between the coefficient of permeability and the uniformity coefficient can be represented by the following formula:

$$
k=15 k_{d} /\left(C_{U}+8\right)
$$

- The coefficient of permeability can be calculated when $C_{U}=$ 5 or $C_{U}=10$, provided $k_{C_{U}=5}$ or $k_{C_{U}=10}$ is known:

$$
\begin{aligned}
& k=15 k_{C_{U}=5} /\left(C_{U}+10\right) \\
& k=15 k_{C_{U}=10} /\left(C_{U}+5\right)
\end{aligned}
$$

- For grain sizes $d_{10}=0.04-0.32$, the range in which measurements are valid can be identified in $\mathrm{mm}$ for the uniformity coefficient values shown in Table 2 .

Tab. 2. A few characteristics of the measurement series

\begin{tabular}{cccc}
\hline $\begin{array}{c}\text { measurement } \\
\text { series }\end{array}$ & validity & $\begin{array}{c}\text { distance } \\
\text { between } \\
\text { boundary } \\
\text { curves }\end{array}$ & $\begin{array}{c}\text { Corner point of } \\
\text { top boundary } \\
\text { curve }\end{array}$ \\
\hline I. & $C_{U}=9-245$ & $9-11$ & Not present \\
\hline II. & $C_{U}=13-200$ & $3,2-3,5$ & Not present \\
\hline III. & $C_{U}=9-340$ & $3,4-6,6$ & $C_{U}=\sim 110$ \\
\hline IV. & $C_{U}=5-500$ & $3,3-3,4$ & $C_{U}=100-120$ \\
\hline V. & $C_{U}=3-550$ & $\sim 2,0$ & $C_{U}=100-160$ \\
\hline
\end{tabular}

\section{Conclusions}

Coefficient of permeability studies played a reduced role in international soil mechanics research after the 1970s, as researchers were occupied with other themes. Hungary was no exception in that very little attention was devoted to this area [15, 19, 21].

There are several uncertainties, and several opportunities for error in determining the $k$ factor. The coefficient of permeability depends on many factors, but relying on a single grain diameter seems to be insufficient for the purposes of determining it despite of the overriding application of $d_{10}$ both in this study and as the common approach. How the uniformity coefficient influences the coefficient of permeability used to be ignored by research or was treated as a secondary aspect. Measurements have demonstrated that the uniformity coefficient can be responsible for variances up to an order of magnitude, which is substantially larger than the impact of water viscosity changing due to temperature changes. 


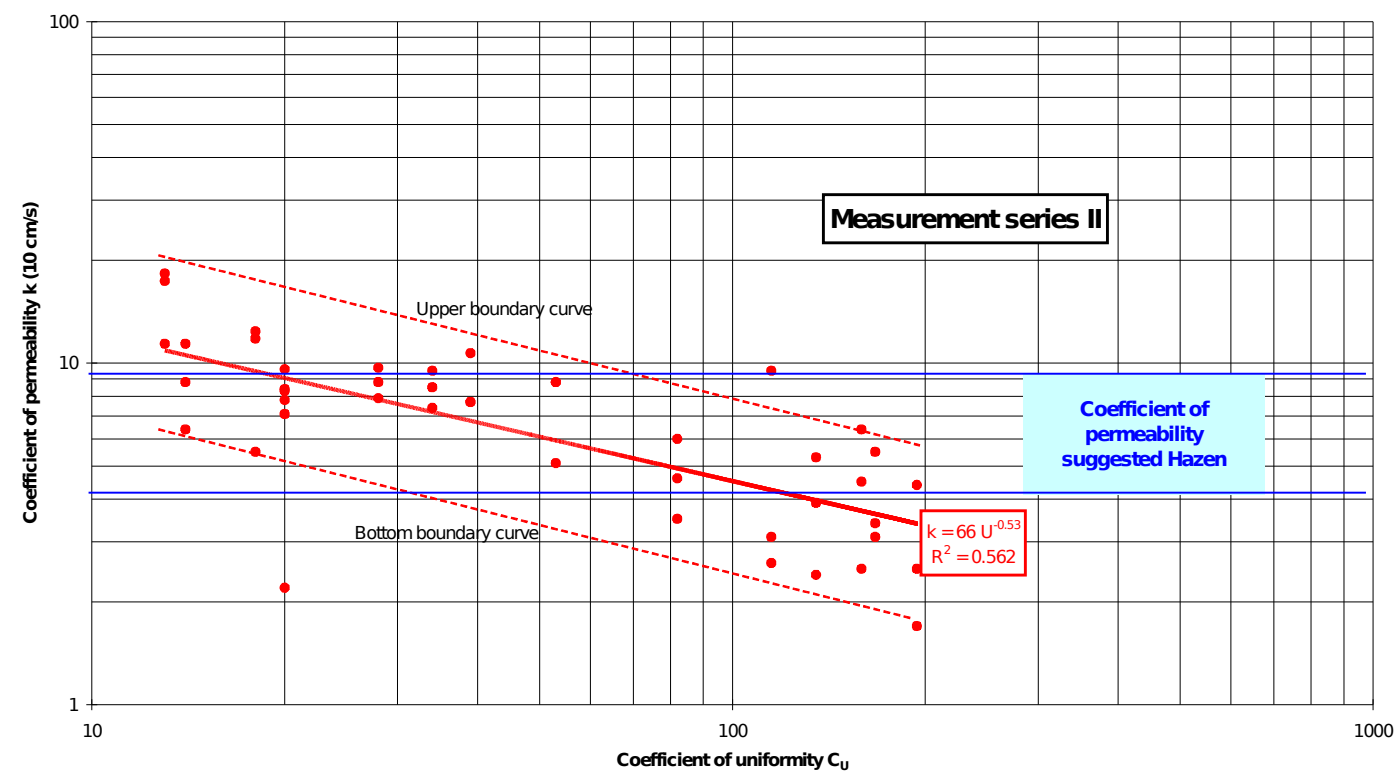

Fig. 6. Measurement series II and the Hazen's permeability

The incidence of soils with uniformity coefficients at $C_{U}>$ 100 is rare in natural circumstances, yet increasing the scope of studies to cover this range is not indifferent as it allows us to discover tendencies. Measurement results offered unquestionable evidence of the differences triggered by the change of the uniformity coefficient. With $d_{10}$ kept constant, the coefficient of permeability of finely graded soils decreases as the uniformity coefficient increases, and grain washout may also play a role in addition to seepage if $C_{U}>100$.

The findings listed above are lowers to make the following conclusions in respect of hydraulic soil failure and boil formation:

- When comparing two soil types with identical $d_{10}$ values, the finely grated type is likely to have a lower coefficient of permeability, which offers greater resistance to flow.

- Being lower than expected, the coefficient of permeability associated with well graded soils has two security consequences: negligence leading to poorer security in cases where the top soil of the protected side of a dyke is involved and safety enhancement in cases involving a layer below a cohesive top layer.

- Grain washout may occur with finely graded soils, which is similar (as a phenomenon) to that occurring when soil is being washed away during the formation of a boil, the physical content is different, though. The process of suffusion (which was replicated in some of the laboratory tests) did not trigger soil failure, as the rough skeletal structure of the soil persisted.

\section{References}

1 Amer A M, Awad A A, Permeability of Cohesionless Soils, Journal of the Geotechnical Engineering Division 100 (1974), no. GT. 12.

2 Beyer W, Zur Bestimmung der Wasserdurchlässigkeit von Kiesen und Sanden aus der Kornverteilungskurve, Wasserwirtschaft und technik (1964).
3 Burmister D M, ASTM Symposium on permeability of soils, ASTM Spec. Tech. Publ., 1954. New York.

4 Hansbo S, Consolidation of Clay with Special Reference to Influence of Vertical Sand Drains, No. 14., Sweedish Geotechnical Institute, 1960.

5 Hazen A, The filtration of public water-supplies, 1875. New York.

6 Holz R D, Broms B B, Long-Term Loading Tests at Ska-Edeby Sweeden, Proceedings of the ASCE Speciality Conference on Performance of Earth and Earth-Supported Structures (Purdue University, 1972), Vol. 1., Part 1., 1972, pp. 435-444.

7 Kenney T C, Lau D., Ofoegbu G I, Permeability of Compacted Granular Materials, Canadian Geotechnical Journal 21 (1984), no. 4, 726-729.

8 Kovács Gy, Szivárgás hidraulikája, Akadémiai Kiadó, 1972. Budapest.

9 Kozeny J, Über capillare Leitung des Wassers in Boden, Vol. 136, 1927. Sitzungsberichre der Wiener Akademie der Wessenschaften.

10 Look B G, Handbook of geotechnical investigation and design tables, Taylor and Francis Group, 2007. London.

11 Nagy L, Jól graduált talajok szivárgási tényezójének meghatározása, 1995. OMFB által támogatott kutatás.

12 _ Finomszemcsés talajok áteresztóképessége, Közúti és Mélyépítéstudományi Szemle 58 (2008), no. 5-6, 33-40.

13 __ Jól graduált talajok áteresztóképességi együtthatója, Közúti és Mélyépítéstudományi Szemle 58 (2008), no. 8, 23-27.

14 Palotás L, Mérnöki kézikönyv, Múszaki könyvkiadó, 1978. Budapest.

15 Pétery $\mathbf{K}, A z$ áteresztóképességi együttható meghatározhatósága és értékének változása, Mélyépítéstudományi Szemle (1982), 485-487.

16 Rózsa L, Alapozás kézikönyve, Mûszaki könyvkiadó, 1977. Budapest.

17 Shahabi A A, Das B M, Tarquin A J, An Empirical Relation for Coeffcient of Permeability of Sand, Fourth Australia-New Zealand Conference on Geomechanics (1984), Vol. 1., 1984, pp. 54-57.

18 Somerville S H, Control of grounwater for temporary works, CIRIA, 1986.

19 Szepessy J, Vízvezetố képességi együttható meghatározása árvízvédelmi töltések altalajában, VITUKI, 1985.

20 US Department of Navy Design Manual, Soil Mechanics, Foundations and Earth Structures, US Government Printing Office, Washington DC, 1971. NAFAC DM-7.

21 Varga L, A talajok áteresztóképességének laboratóriumi méréséról, Mélyépítéstudományi Szemle (1983). 